\title{
Radio wobec zjawiska sieciowania i formatowania
} \begin{tabular}{l|l} 
Kinga Zdrojewska & $\begin{array}{l}\text { Wydział Prawa, Administracji i Stosunków Międzynarodowych } \\
\text { Krakowska Akademia im. Andrzeja Frycza Modrzewskiego }\end{array}$
\end{tabular}

Słowa kluczowe:

stacje komercyjne, rynek radiowy,

sieciowanie, formatowanie, internet

\section{Streszczenie}

Na polskim rynku nadawców radiowych działają zarówno stacje publiczne, jak i komercyjne. Pojawienie się tych drugich możliwe było dopiero po $1989 \mathrm{r}$. wraz z demokratyzacją życia społeczno-politycznego w Polsce. Wcześniej rynek ten był w naszym kraju nieznany, choć oczywiście poza granicami stacje prywatne były bardzo popularne i nadawały swój program w ramach określonego formatu. Zjawisko formatowania oraz towarzyszące mu sieciowanie to dzisiaj codzienność polskich nadawców radiowych. Procesy te zdominowały funkcjonowanie mediów. Dodatkowo popularność internetu jako nowego kanału dotarcia do odbiorców sprawiła, że stacje musiały dopasować swą ofertę do rosnących oczekiwań.

Stacje komercyjne na polskim rynku funkcjonują najczęściej w ramach określonych grup kapitałowych. Ich oferta programowa przekłada się na atrakcyjność (popularność) stacji, ta zaś na wyniki słuchalności.

Artykuł przedstawia kondycję komercyjnych stacji radiowych na rynku i ich działania w internecie.

\section{Abstract}

Keywords: radio, format,

listening,

commercial

broadcasters, network, media group.

The Polish market of radio broadcasters operates both-public and commercial stations. The commercial one was possible only after 1989 with the democratization of social and political life in Poland. Before ' 89 this market was unknown in our country, although of course abroad, private stations were very popular and broadcasted their program within a certain format. Nowdays formatting and networking is known everyday in Polish radio broadcasters. These processes have somehow dominated media. The popularity of the Internet as a new channel of reaching consumers has made, that the stations have to adapt their programms to the growing needs. Commercial stations on the Polish market operate mostly within certain capital groups. Their program's offer affecsts into the attractiveness (popularity) of the station, and this results in the audience.

The article presents the condition of commercial radio stations on the market and their actions on the Internet 


\section{Wstęp}

Historia radia w epoce telewizji jest więcej niż historią stacji, sieci, formatów, operatorów i regulatorów. Jest to opowieść o słuchaczach. Żyją oni w miastach, miasteczkach i na wsiach, nie zaś na „rynkach" (markets). I mają także potrzeby siły nabywczej (Fornatale, Milles 1980:XV)

- takimi słowami Peter Fornatale i Joshua Mills rozpoczynali na początku lat 80. swoją książkę o radiu w epoce telewizji. Nakreślona przez nich rzeczywistość radiowa związana była wprawdzie z USA, ale opisane przyzwyczajenia dotyczące odbioru radia, jego funkcji, formatów i ich typów są po dziś aktualne także w Polsce, gdy radio funkcjonuje w epoce internetu.

\section{Droga do powstania nadawców komercyjnych}

Aby przyjrzeć się kondycji radia na polskim rynku medialnym, należy najpierw dostrzec i zrozumieć wszystkie zjawiska, które w ciągu ostatnich 25 lat zaistniały w obrębie rynku nadawców. Szczególnie ważne jest to, że polski rynek radiowy stał się interesujący na skutek przemian polityczno-społecznych po 1989 r. Jak zauważa Stanisław Jędrzejewski, wówczas „otworzyły się zupełnie inne niż dotychczas możliwości rozwoju mediów"(Jędrzejewski 2007: 162). Przemiany społeczno-gospodarczo-polityczne, jakie nastąpiły po obradach Okrągłego Stołu (w szczególności zaś po debatach tak zwanego podstolika do spraw medialnych), przyniosły wiele nowości. Należy tu zaliczyć zarówno reaktywowanie Ministerstwa Łączności (1990 r.), jak i wznowienie działalności Polskiej Agencji Radiokomunikacyjnej (1991 r.), co sprawiło, że

monopol państwa w dziedzinie radiofonii i telewizji został zniesiony ustawą z 23 listopada 1990 roku o łączności, w zakresie kolportażu w 1988 roku. Działalność poligraficzna, obrót papierem, urządzeniami poligraficznymi poddane zostały takim samym rygorom prawnym, jak prowadzenie działalności gospodarczej w innych dziedzinach (Dobosz 2011: 36-41),

a demokratyzacja życia politycznego i pojawienie się gospodarki wolnorynkowej doprowadziły do tego, że w eterze zaczęły nadawać stacje komercyjne dotąd nieznane, bo "wraz ze zmianą ustroju nastąpiło złamanie monopolu państwowego nadawcy" (Mielczarek 2007: 143).

Ustawa o radiofonii i telewizji, na mocy której przekształcono państwowe media audiowizualne, weszła w życie 1 marca 1993 r. Media stały się odtąd ogólnokrajowymi spółkami akcyjnymi Skarbu Państwa - Polskim Radiem SA i Telewizją Polską, natomiast w regionach powołano 17 jednoosobowych spółek radiowych. Ustawa o radiofonii i telewizji wprowadziła też między innymi konieczność ubiegania się o koncesję(Dz. U. z 1993 r. Nr 7, poz. 34 art. 33 ust.1) Na jej mocy powołano do życia organ nadzorujący działanie mediów - Krajową Radę Radiofonii i Telewizji. Gdy KRRiT ogłosiła pierwszy proces koncesyjny, przystąpiły do niego zarówno stacje już nadające program, 
jak i ci nadawcy, którzy dopiero chcieli rozpocząć swoją działalność. Wcześniej nie istniały prawne regulacje w zakresie emisji dla mediów komercyjnych. Większość stacji nadawała swój program w oparciu o treści zawarte w Ustawie o stosunku państwa do kościoła katolickiego, w której określono warunki zakładania stacji katolickich. Warto zaznaczyć, że pierwsze komercyjne rozgłośnie rozpoczynały swą działalność w oparciu o wyżej wspomnianą ustawę (Episkopat zawarł z Ministerstwem Łączności umowę o przydziale częstotliwości do emisji programu radiowego w poszczególnych diecezjach). Jednakże sytuacja na komercyjnym rynku radiowym była „swoistym bezprawiem" (Gałka 2013: 221), bo powstające rozgłośnie prywatne działały bez koncesji.

Wraz z pojawieniem się stacji komercyjnych na rynku rozpoczęła się walka rozgłośni o słuchaczy i pozyskanie ich uwagi, bo liczba odbiorców była wprost proporcjonalna do zysków z tytułu sprzedaży czasu antenowego. Ten zaś był i jest podstawowym źródłem wpływów celem utrzymania się komercyjnych podmiotów na rynku (stacje komercyjne - w przeciwieństwie do publicznych - nie uczestniczą w podziale wpływów abonamentowych). Jak zauważa Mirosław Lakomy,

od początku istnienia media elektroniczne poszukiwały najwłaściwszego modelu finansowania swojej działalności. (...) Rosnące koszty utrzymania mediów sprawiają, że trwają gorączkowe poszukiwania dodatkowych przychodów z innych źródeł. Jednym z nich jest technologia SMS-ów, dzięki której media odnotowują zwiększone dochody ze swojej działalności (Lakomy, Lakomy 2013: 63, 65).

Mowa tu o SMS-ach premium, czyli takich, których wysłanie wiąże się z koniecznością poniesienia dodatkowej, wcześniej znanej opłaty. Ten sposób pozyskiwania dodatkowych środków finansowych dla stacji radiowej wykorzystywany jest w konkursach i do komunikacji ze słuchaczem (pytanie na antenie, odpowiedź w SMS-ie), ale pamiętać należy, że w dobie mediów społecznościowych, w których uczestnictwo jest tyleż popularne, co darmowe, system wiadomości tekstowych nie może stanowić pewnego źródła dochodu dla nadawców. Tak więc przychody reklamowe, czy, nazywając to precyzyjniej, działania promocyjno-sprzedażowe są podstawowym źródłem finansowania komercyjnych stacji radiowych, co jest potwierdzeniem tezy Roberta Picarda,

mówiącej o wyraźnym związku rynku przekazów z rynkiem reklamy. Mechanizm ów opiera się na korelacji zachodzącej pomiędzy wielkością audytorium i udziałem w rynku reklam (Lakomy 2012: 133).

Rola komercyjnego radia, jego funkcje, cele, grupy docelowe to - z racji wykonywanego zawodu dziennikarza radiowego - temat szczególnie mi bliski. Ograniczając się do najważniejszych zmian, jakie na tym rynku wydarzyły się w ciągu ostatnich 25 lat, spróbuję przedstawić zagadnienia, których konsekwencją są działania dotyczące formatowania, a więc także charakteru programu (audycji), sieciowania, upodabniania się stacji do siebie lub ich hybrydyzacji, czyli mieszania styli. Zwrócę również uwagę na rolę internetu jako nowego kanału przekazu sygnału radiowego. 


\section{Sieciowanie stacji radiowych}

Zjawiskiem, które zdominowało komercyjny sektor radiowy w ostatnich latach, jest sieciowanie. Włączanie stacji do wspólnej sieci po raz pierwszy w sektorze komercyjnych rozgłośni w Polsce zauważono wraz z drugim procesem koncesyjnym (od 2000 roku). Wtedy stacje rozpoczęły składanie do KRRiT wniosków o przedłużenie koncesji na emisję programu. Ważną decyzją, podjętą wówczas przez KRRiT, było przyznanie ogólnopolskiemu nadawcy - radiu RMF FM - koncesji bez tak zwanych rozszczepień lokalnych. Dawały one możliwość emisji lokalnych pasm programowych, zawierających nie tylko wiadomości z regionu czy prognozę pogody w określonym mieście, ale również bloków komercyjnych dla lokalnych kontrahentów. Był to zatem moment zwrotny na rynku nie tylko reklamowym (stacje lokalne przegrywały dotąd z lokalnymi multiplikacjami sygnału RMF), ale także własnościowym, zapoczątkował bowiem zjawisko sieciowania i formatowania. Jak już kiedyś odnotowałam - przyznanie radiu RMF koncesji na nadawanie bez możliwości emisji lokalnych pasm programowych

uratowało wiele lokalnych nadawców, dając im szansę zaistnienia na tym rynku i udział w podziale środków finansowych z tytułu przychodów z reklam. Otworzyło to także możliwości powstania, a potem także rozwoju sieci radiowych, które dzięki temu, że grupowały kilka stacji radiowych z różnych obszarów, stwarzały szansę na wspólne tworzenie np. strategii promocyjnej i wzrost atrakcyjności na lokalnych rynkach (Zdrojewska 2012: 148).

\section{Skutki sieciowania}

Jak zauważa Dennis McQuail, „,wejście w wiele sektorów rynku mediów jest niemożliwe bez dużych zasobów kapitału" (McQuail 2008: 241), a sieciowanie to proces łączenia się stacji na płaszczyźnie czy to sprzedaży czasu antenowego, czy też wspólnych pasm programowych lub akcji promocyjnych. W zamyśle ma na celu wzrost atrakcyjności programu przy równoczesnym spadku kosztów (partycypacja finansowa poszczególnych stacji w ramach danego projektu) i przyczynienie się do wzrostu słuchalności. Sieciowanie i formatowanie to zjawiska ściśle ze sobą połączone. Programy emitowane w ramach sieci są tworzone w oparciu o konkretny format, dla dobranej grupy docelowej. Proces sieciowania po 2000 roku przybrał na sile i

tak oto spółki producenckie (...) zaczęły tworzyć coraz więcej programu do emisji na kilku lokalnych antenach. Z ekonomicznego punktu widzenia pomysł okazał się strzałem w dziesiątkę (...). Skutkiem łączenia się stacji w sieci była unifikacja programu i powstanie tak zwanych stacji sformatowanych, nadających program dla określonej grupy odbiorców i w określonym klimacie muzycznym (Zdrojewska 2012: 156).

Wykaz aktualnie nadających, niezrzeszonych stacji radiowych (dostępny na stronie http://www.emsoft.strefa.pl/rad_s90.htm) informuje o 59 działających rozgłośniach, choć po zakupie krakowskiego radia KRK FM przez grupę Agora SA jest ich 58. 
Dla uzupełnienia posłużę się danymi z 2010 roku, gdy „na 220 wydanych koncesji 126 stanowili nadawcy działający w ramach jakiejś sieci radiowej" (Gałka 2012: 125). Ciężko jednak stwierdzić, w jakim stopniu stacje te są istotnie niezależne, a w jakim korzystają z możliwości wspólnej sprzedaży czasu antenowego, wiadomości i serwisów informacyjnych (kraj/świat), programów (audycji), prowadzących. Jak zauważa Krajowa Rada w swoim raporcie o stanie radiofonii w Polsce:

problemem branży radiowej jest silna centralizacja wydatków reklamowych w wielkich aglomeracjach przy wyraźnej preferencji dla anten ogólnokrajowych i regionalnych, kosztem przede wszystkim radia lokalnego i w mniejszym stopniu społecznego. Wytwarza to stan nierównowagi, powodując wyraźny niedorozwój radia lokalnego (KRRiT 2012).

W raporcie można przeczytać również, że „najważniejsze tendencje na rynku radiowym w 2003 roku to spadek znaczenia stacji lokalnych na rzecz ogólnopolskich" (KRRiT 2012).

Z kolei w dokumencie z 2005 r. Obrona lokalności i demokracji lokalnej. Strategia działania Krajowej Rady Radiofonii i Telewizji na rzecz ochrony lokalnego charakteru i pluralizmu oferty programowej w lokalnych mediach elektronicznych nadmieniono, że „w sytuacji konsolidacji rozgłośni trudno mówić o lokalnym radiu, które spełniałoby funkcję integracji społeczności lokalnej w ramach tzw. «małej ojczyzny»" (KRRiT 2012). Zauważono także, że „brak promocji wydarzeń o charakterze społeczno-kulturalnym sprzyja atomizacji społeczności, ograniczając jej dostęp do lokalnie zakotwiczonej informacji i rozrywki" (KRRiT 2012).

Nietrudno więc zauważyć, że sieciowanie, choć ogranicza koszta nadawców, ogranicza równocześnie odbiorcom różnorodność przekazu i prawdziwą lokalność.

\section{Początki formatowania stacji}

Procesem, który towarzyszy sieciowaniu jest formatowanie. W dużym uproszczeniu "formatowanie radia jest pewną formą gry rynkowej i radzenia sobie z konkurencją" (Lakomy 2013: 26). Stanisław Jędrzejewski definiuje format jako:

pewien styl stacji, ustalony jednoznaczny wzór audycji, odzwierciedlający jej filozofię działania, ukierunkowany na oczekiwania określonego rynku, dopasowany do potrzeb określonej grupy lub grup słuchaczy wybór struktury, treści i sposobu prezentacji programu radiowego (Jędrzejewski 2007: 352).

Warto dodać, że formatowanie stacji radiowych zostało zapoczątkowane w latach 60 . XX wieku w Stanach Zjednoczonych i Wielkiej Brytanii. Po dziś dzień ma ono na celu stworzenie stacji niemal idealnej dla określonej grupy słuchaczy, bowiem 
wszystkie funkcje ideowe, programowe, marketingowe i organizacyjne przyporządkowane są obsłudze specyficznego segmentu rynkowego, który jest dobrze zdefiniowany w kategoriach socjo-demograficznych (Kowalski 2001: 248).

\section{Najpopularniejsze formaty stacji radiowych}

Mając na myśli format, najczęściej mówimy o stylu (formacie) muzycznym (np. rockowym, CHR, czyli „hity na czasie", oldies, czyli złote przeboje, soul, funk, itd.). Format może jednak zakładać inny niż muzyczny charakter programu, np. informacyjny, publicystyczny, religijny, miejski. Grażyna Stachyra w publikacji poświęconej gatunkom audycji w radiu sformatowanym wylicza prawie 30 formatów stacji radiowych, zaznaczając jednak, że „nie wszystkie z nich mają swe odpowiedniki na polskim rynku radiowym" (Stachyra 2008: 31-33).

Co ważne, formaty w ramach jednej stacji mogą się łączyć, i tak na przykład stacja religijna może być równocześnie stacją o formacie muzycznym pop (łagodne przeboje), a stacja informacyjno-publicystyczna grać przeboje jazzowe. Na polskim rynku radiów komercyjnych dominujące są dwa formaty - AC (Adult Contemporary), czyli największe i najpopularniejsze przeboje, w którym swój program realizują dwaj najwięksi komercyjni nadawcy na rynku radiowym (stacje RMF FM i Radio Zet) oraz format CHR (Contemporary Hit Radio), czyli aktualne hity (gorące przeboje), który realizują dwie sieci radiowe - Radio Eska i RMF Maxxx.

W walce o słuchacza wiele można zdziałać, decydując się na format oldies, czyli tak zwane złote przeboje. Uważa się, że dał on początek sformatowanym stacjom radiowym w Polsce, za początek formatowania uznaje się bowiem powstanie sieci Złote Przeboje Wydawnictwa Agora w 1998 roku. Wówczas założono spółkę AC Radio, której zadaniem było „odkupywanie udziałów od lokalnych stacji radiowych, które przed przystąpieniem do drugiego procesu koncesyjnego utraciły płynność finansową" (Sułek 2009: 267).

W ostatnich kilkunastu miesiącach formatem, który zburzył ułożony przewidywalnie co do rodzaju granej muzyki rynek stacji komercyjnych w Polsce (co dowodzi, że radio ciągle się zmienia), jest format disco ze szczególnym uwzględnieniem nurtu disco polo. W formacie tym nadają stacje Vox i Plus - ta druga, co ciekawe, jest równocześnie stacją religijną (katolicką). W przypadku radia Vox FM „zmiana formatu muzycznego na adult disco, modyfikacja programu i rozpoczęcie nadawania jako sieć ponadregionalna spowodowały wzrost słuchalności stacji" (Wirtualnemedia 2015).

Chciałabym zauważyć, że formularze koncesyjne, które nadawcy oraz wnioskujący o koncesję, a zatem potencjalni nadawcy wypełniają i składają do KRRiT, nie zawierają słowa format. Jest $w$ nich mowa jedynie o charakterze programu, który stacja będzie emitować, tak więc format to bardziej znak czasów i skutek fuzji oraz zmian 
kapitałowych niż to, co stanowi istotę audycji stacji radiowej. Jej fundamentem pozostaje bowiem styl, charakter, który nadawca deklaruje realizować.

\section{Grupy medialne na polskim rynku nadawców radiowych}

Każde radio komercyjne musi pozyskiwać środki finansowe na swoją działalność. Wynika to z praw rynku, więc stacja, tak jak wszystkie dobra konsumpcyjne, podlega ich prawom. O obecności w świadomości konsumentów (w tym wypadku słuchaczy) decydują podaż i popyt. Im większe zapotrzebowanie (wyższa słuchalność), tym lepsza pozycja stacji na rynku i tym wyższe ceny czasu antenowego (reklam). Wzrost słuchalności przy równoczesnej minimalizacji kosztów towarzyszyły nadawcom od początku ich działalności. W moim artykule zatytułowanym Współczesny radiowy rynek stacji komercyjnych w Polsce, który ukazał się drukiem w 2015 r., nadmieniałam już, że

komercyjny rynek radiowy w Polsce to medialny obszar uporządkowany i dobrze znany. Tworzą go stacje o zasięgu ogólnopolskim i sieci radiowe, których dążeniem jest, by lokalnymi nadajnikami pokryć całą Polskę. Oczywiście na rynku funkcjonują także stacje niezależne, choć ich liczba systematycznie spada, bo koszta utrzymania radia na rynku są wysokie (Zdrojewska 2015: 159).

To właśnie troska o finanse sprawiła, że zjawiska sieciowania i formatowania stały się popularne i są tak konsekwentnie realizowane przez nadawców radiowych w Polsce. Skutkiem tych działań mamy aktualnie, a więc 25 lat po zaistnieniu pierwszych stacji komercyjnych, obecnych na rynku pięciu graczy wchodzących w skład określonych grup medialnych. Są to:

1. Spółka Bauer, która jest właścicielem Radia RMF FM wraz z siecią młodzieżową RMF Maxxx i siecią dla „bardziej wymagających słuchaczy - RMF Classic” (Bauer 2015).

Łączny udział w czasie słuchania stacji radiowych Grupy RMF wśród osób w wieku 16-49 lat wynosi 35,4\%, a łączny zasięg dzienny w tej grupie wiekowej wynosi 41,1\% (Radio Track Millward Brown, udział w czasie słuchania, zasięg dzienny 2015).

2. Grupa radiowa Eurozet, w skład której wchodzą takie stacje radiowe, jak Radio Zet, Radio Zet Chilli, Radio Zet Gold, Antyradio, a także Radio PLUS, które jednak zarządzane jest przez inną, konkurencyjną grupę medialną.

3. Wydawnictwo Agora jako właściciel sieci Złote Przeboje, TOK FM, Rock Radia.

4. Grupa Radiowa Time (Zjednoczone Przedsiębiorstwa Rozrywkowe) z Radiem Eska, Vox FM, Eską Rock, Radiem WaWa, a także wymienianą już siecią Radia Plus. Włodarze podmiotów skupionych wokół ZPR deklarują: „naszych stacji radiowych słucha miesięcznie 12,8 mln Polaków" (Break Time, fala: sierpień-październik 2014).

5. Radio Maryja - koncesja wydana na Zgromadzenie Najświętszego Odkupiciela (Ojcowie Redemptoryści) z siedzibą w Toruniu. Stacja ta świetnie radzi sobie w warunkach 
konkurencji wolnorynkowej. Choć ma status nadawcy społecznego', utrzymuje się z dobrowolnych ofiar swych słuchaczy. Rozgłośnia ta tworzy swój program

w stałym poczuciu zagrożenia, wróg czai się wszędzie, trzeba być ciągle gotowym do walki. Zagrożenie-wróg, w istocie zawsze ten sam, przybiera jednak różne formy. Przedtem były to mocarstwa, które doprowadziły do rozbiorów, potem komunizm, a teraz jest nim zachodnia liberalna demokracja (Pokorna-Ignatowicz 2003: 199).

\section{Badania słuchalności}

Stacje wchodzące w skład Grupy Eurozet, Agory, Grupy RMF i Time SA przystępują do badań radiowych „realizowanych przez Komitet Badań Radiowych Radio Track Instytutu Millward SMG/KRC" (BadaniaRadiowe 2015). Z badań tych każdy nadawca jest w stanie wyodrębnić (opisać) najbardziej atrakcyjną grupę docelową, najchętniej słuchane pasmo w swojej stacji i tym samym w należyty sposób pozycjonować się jako lider przy potencjalnym reklamodawcy w kontekście określonego pasma programowego. Warto zauważyć, że

radio jest silnie związane $z$ formatem oraz rynkiem geograficznym. Rynek radiowy jest swoistą mieszanką wielu rynków działających równolegle. Słuchacze mają ogromną łatwość przemieszczania się między tymi rynkami w zależności od chwilowych potrzeb i upodobań (Kowalski, Jung 2006: 178).

Mimo to wyniki badań słuchalności dowodzą, że niekwestionowanym zwycięzcą rankingu słuchalności jest radio RMF. Pierwsza dziesiątka najchętniej słuchanych stacji o zasięgu ogólnopolskim i sieci radiowych za okres od lutego do kwietnia 2015 r. przedstawia się następująco:

Dane odnośnie do słuchalności (zasięg dzienny)2:

1. RMF FM $-25,5 \%$

2. Radio Zet $-13,4 \%$

3. Jedynka $($ I PR) $-9,3 \%$

4. Eska $-7,9 \%$

5. Trójka $($ III PR) - 7,3\%

1 Zgodnie z ustawą o radiofonii i telewizji: (art.4 pkt 10) nadawcą społecznym jest nadawca: a) którego program upowszechnia działalność wychowawczą i edukacyjną, działalność charytatywną, respektuje chrześcijański system wartości, za podstawę przyjmując uniwersalne zasady etyki, oraz zmierza do ugruntowania tożsamości narodowej; b) w którego programie nie są rozpowszechniane audycje ani inne przekazy, o których mowa w art. 18 ust.5; c) który nie nadaje przekazów handlowych; d) który nie pobiera opłat z tytułu rozpowszechniania, rozprowadzania lub odbierania jego programu.

2 Na podstawie: www.badaniaradiowe.pl [dostęp: 02.06.2015].

3 Program Pierwszy Polskiego Radia, nadaje od ponad 90 lat.

4 Program Trzeci Polskiego Radia, nadaje od 60 lat, zawsze w paśmie UKF (Winnicka, Łazarewicz 2012; 13). 
6. Audytorium $17^{5}-5,4 \%$

7. Vox FM - 4, $1 \%$

8. Złote Przeboje - 3,4\%

9. RMF Maxxx - 2,9\%

10. Radio Maryja - $1,8 \%$

W zestawieniu znajdują się także stacje nadawcy publicznego - Polskiego Radia (Jedynka, Trójka, Audytorium 17), które jednak nie partycypują finansowo w kosztach badań Komitetu Badań Radiowych.

\section{Internetowa strona stacji radiowych}

Wszystkie stacje działające na polskim rynku radiowym, niezależnie od tego, czy są komercyjne, czy publiczne, mają swoje strony internetowe. Często są to wręcz platformy internetowe, rozbudowane i dające więcej możliwości swoim odbiorcom niż radio tradycyjnie pojmowane. Tak, jak „świat i ludzi zmienił kiedyś druk, zmieniały kolejne nowe media. Jednak żaden chyba nie wpłynął na ludzkość tak, jak internet" (Bajka 2008: 204). Zważywszy na to, że „internet jest dobrem wspólnym, (...) jest dobrem szczególnym, mającym wiele niepowtarzalnych cech” (Hofmokl 2009: 228), należy inwestować w jego rozwój i oferować odbiorcom, a więc także słuchaczom konkretnej stacji radiowej, należytą wersję elektroniczną ulubionego radia. Radio w internecie to możliwość odbioru stacji radiowej przez internetowy player, to także szansa na odsłuchiwanie archiwalnych audycji, to możliwość dostrzeżenia tego, co przez radio pokazywane nie jest, przede wszystkim prowadzących audycje (dziennikarzy, prezenterów), nagród w konkursach, teledysków do piosenek granych w stacji. To także kanały z wyselekcjonowaną muzyką - „tak zwane streamy internetowe grające muzykę tylko określonego artysty albo określony jej rodzaj" (Zdrojewska 2011: 85).

O ile „produkt radiowy nie ma cyklu życia” (Kowalski, Jung 2006: 186), o tyle ta sama produkcja zarchiwizowana na stronie internetowej stacji ma swój cykl odsłon, w których mierzona jest popularność konkretnych podcastów, czyli dostępnych na stronie internetowej stacji dźwiękowych plików, audycji. Jak zauważa Stanisław Jędrzejewski:

dla tradycyjnych rozgłośni internet jest jeszcze jednym sposobem docierania do słuchaczy (...). Internauci wybór ten motywują przede wszystkim mniejszą liczbą reklam emitowanych w stacjach internetowych (54\%), większą liczbą utworów muzycznych (52\%) oraz lepszą jakościowo playlistą (50\%). Dużej części internetowych słuchaczy odpowiada też całkowity brak słowa mówionego (29\%) (Jędrzejewski 2010: 231-232).

Bez wersji internetowych tradycyjne media nie są atrakcyjne, w szczególności dla młodego pokolenia, które internet traktuje tak, jak niegdyś postrzegano odbiornik telewizyjny. Ponadto

\footnotetext{
5 Wszystkie rozgłośnie regionalne Polskiego Radia
} 
siła radia polega na jego niskich kosztach i możliwościach odbioru praktycznie wszędzie. Lecz jedną ze słabości tradycyjnego radia analogowego jest fakt, że programy są ściśle powiązane z porą odbioru, ograniczonym zakresem częstotliwości, nie są dostosowane w pełni do upodobań słuchaczy (Jędrzejewski 2012:155).

Bariery te znosi radio słuchane, a nawet oglądane w internecie.

\section{Zakończenie}

Dla wielu odbiorców

rozwój technik informacyjnych budzi dzisiaj niepokoje analogiczne do tych, jakie towarzyszyły świadkom wprowadzenia do użytku maszyny parowej, elektryczności i pierwszych samochodów. Tego, co nowe, obawiamy się najczęściej dlatego, że otwiera przed nami nieznane horyzonty (Chyrowicz 2008: 8),

ale równocześnie pamiętać należy o możliwościach, jakie daje tradycyjnym mediom właśnie internet. Wymienię tu szansę dotarcia dzięki wspomnianym podcastom do większej liczby odbiorców w dowolnym miejscu na świecie - o dowolnej porze, wielokrotnie, z większą, pełniejszą wersją wiadomości znanych z anteny on air, wielowątkowość dyskusji, złożoność wypowiedzi, bogactwo zdjęć i materiałów video - niemożliwych do przekazania tradycyjną drogą. Warto o tym pamiętać, bo radio w epoce internetu to coś więcej niż tylko przekaz audio. Jak zauważa Jan Kreft,

w warunkach postępującej konwergencji mediów konkurencja intermedialna oznacza nie tylko wzrost liczby podmiotów zabiegających o uwagę tych samych słuchaczy i te same budżety reklamowe. Stwarza też ona szanse wynikające ze słabości konkurencji, jej zmniejszających się możliwości w podtrzymywaniu dotychczasowego modelu biznesu (Kreft 2016: 29).

To właśnie rozwój nowych technologii sprawia, że radio staje się „małą telewizją”, a atrakcyjność stacji w internecie jest często większa niż gdy słucha się ich tradycyjną drogą, a więc przy użyciu odbiornika. Raz jeszcze pragnę powołać się na słowa Stanisława Jędrzejewskiego, który starając się określić drogi rozwoju radia stwierdza, że "kwestią pierwszoplanową wydaje się zarządzanie zmianą" (Jędrzejewski 2016: 26).

Zmiana technologiczna jest jednak w mojej ocenie przede wszystkim szansą, którą nadawcy winni wykorzystać celem ciągłego uatrakcyjniania swej oferty programowej. Równocześnie nie wolno zapominać o jakości, co niestety często nie jest uwzględniane w budżetach stacji. Wierzę, że zwrot w stronę jakości będzie nieuniknioną drogą w przyszłości polskiej radiofonii. Życzyłabym sobie, aby stało się tak zwłaszcza w sektorze komercyjnych nadawców. 


\section{Literatura}

Agora, 2015, Informacje o stacjach grupy http://www.agora.pl/agora/0,111460.html\#TRNavSST [dostęp: 2.05.2015].

Bajka Z., 2008, Historia mediów, Kraków: ABCmedia.

Bauer, 2015, Stacje skupione w grupie RMF FM http://www.bauer.pl/ [dostęp: 3.06.2015].

Bonikowska M. (red.), 2009, Media a wyzwania XXI wieku, Warszawa, Trio.

Chudziński E. (red.), 2007, Słownik wiedzy o mediach, Bielsko-Biała: Dom Wydawniczy PWN.

Chyrowicz B. (red.), 2003, Społeczeństwo informacyjne. Szansa czy zagrożenie, Lublin: Towarzystwo Naukowe Katolickiego Uniwersytetu Lubelskiego.

Dobosz I., 2011, Prawo prasowe, Warszawa: Wolters Kluwer.

EMSoft, 2015, Wykaz stacji radiowych niezsieciowanych, http://www.emsoft.strefa.pl/rad_s90.htm [dostęp: 1.06.2015]. EuroZet, 2015, Informacje o stacjach grupy, http://www.eurozet.pl/ [dostęp: 2 06.2015].

Fornatale P., Milles J., 1980, Radio in the Television Age, New York: The Overlook Press Woodstock.

Francuz P., Jędrzejewski S. (red.), 2012, Nowe media i komunikowanie wizualne, Lublin: Wydawnictwo KUL.

Gnela B., Pokorna-Ignatowicz K.(red), 2015, Państwo i społeczeństwo, Kraków: Krakowska Szkoła Wyższa im. Andrzeja Frycza Modrzewskiego.

Hofmokl J., 2009, Internet jako nowe dobro wspólne, Warszawa: Wydawnictwa Akademickie i Profesjonalne.

Jędrzejewski S., 2010, Radiofonia publiczna w Europie w erze cyfrowej, Kraków: UNIVERSITAS.

Jędrzejewski S., 2015, R@dio publicznew Europie, Warszawa: Poltext.

Jung B. (red.), 2001, Media, komunikacja, biznes elektroniczny, Warszawa: Difin S.A.

Komitet Badań Radiowych, 2015, Badania słuchalności stacji radiowych Radio Track Instytutu Millward SMG/KRC, http://www.badaniaradiowe.pl/kbr/index.html [dostęp: 3.06.2015].

Komitet Badań Radiowych, 2015, Kto partycypuje w kosztach badań, http://www.badaniaradiowe.pl/ aktualnosci/20120712.htm [dostęp: 2.06.2015].

Kowalski T., Jung B., 2006, Media na rynku, Warszawa: Wydawnictwa Akademickie i Profesjonalne.

KRRiT, 2012,Obrona lokalności i demokracji lokalnej, http://www.krrit.gov.pl/Data/Files/_public/pliki/ publikacje/strategie/obrona_lokalnosci.pdf [dostęp: 2.04.2012].

KRRiT, 2012, Raport o stanie radiofonii w Polsce, http://www.krrit.gov.pl/Data/Files/_public/pliki/publikacje/raporty/rtv_w_polsce.pdf [dostęp: 2.04.2012].

KRRiT, 2015, Podział środków abonamentowych, http://www.krrit.gov.pl/wyszukiwarka/index,1. html?Scope=http\%3A\%2F\%2Fwww.krrit.gov.pl\%2F\&Query=podzia\%C5\%82+\%C5\%9Brodk\%C3\%B3w+abonamentowych [dostęp: 2.06.2015].

KRRiT, 2015, Wnioski koncesyjne dla nadawców radiowych, http://www.krrit.gov.pl/dla-nadawcow-i-operatorow/koncesje/formularze/ [dostęp: 4.06.2015].

Lakomy M., Lakomy L., 2013, Hazardyzacja mediów, ,Rocznik prasoznawczy”, VII.

Lakomy M., 2012, Rynek radiowy w Polsce, Kraków: WAM.

McQuail D., 2008, Teoria komunikowania masowego, Warszawa: Wydawnictwo Naukowe PWN. 
Mielczarek T., 2007, Monopol, pluralizm, koncentracja, Warszawa: Wydawnictwa Akademickie i Profesjonalne.

Nierenberg B., Kania J., Kreft J. (red.), 2016, Przyszłość dziennikarstwa radiowego, Kraków: Wydawnictwo Uniwersytetu Jagiellońskiego.

Pokorna-Ignatowicz K., 2003, Antyunijne imperium ojca Rydzyka ,"Studia medioznawcze”, nr 5 (15).

Pokorna-Ignatowicz K. (red.), 2012, The Polish Media System, Kraków: Oficyna Wydawnicza AFM.

Pokorna-Ignatowicz K. (red.), 2013, Polski system medialny 1989-2011, Kraków: Oficyna Wydawnicza AFM.

Pokorna-Ignatowicz K., Bierówka J. (red.), 2011, Stare media w obliczu nowych, nowe w obliczu starych, „Media i polityka”, t. 3.

Stachyra G., 2008, Gatunki audycji w radiu sformatowanym, Lublin:Wydawnictwo Uniwersytetu Marii Curie-Skłodowskiej.

Trembicka K., 2008, Oblicza polskich mediów po 1989 roku, Lublin:Wydawnictwo Uniwersytetu Marii Curie-Skłodowskiej.

Ustawa o radiofonii i telewizji, Dz. U. z 1993 r. Nr 7, poz. 34.

Winnicka E., Łazarewicz C., 2012, Zapraszamy do Trójki, Warszawa: Agora.

Wirtualne Media, 2015, Radio VOX podnosi ceny reklam o 40\%, http://www.wirtualnemedia.pl/arty$\mathrm{kul} /$ radio-vox-fm-podnosi-ceny-reklam-o-40-proc [dostęp: 2.06.2015]

ZPR, 2015, Stacje skupione w grupie, www.zpr.pl [dostęp: 2.06.2015]. 